\title{
The Role of Leadership in the Implementation of Administrative Reform at the Indonesian National Institute of Public Administration
}

\author{
Kamaruddin \\ Faculty of Economic and Social Science \\ State Islamic University \\ Pekan Baru, Indonesia \\ alqomaru@gmail.com
}

\author{
Eko Prasojo \\ Faculty of Administrative Science \\ University of Indonesia \\ Depok, Indonesia \\ prasojo1@ui.ac.id
}

\begin{abstract}
Most administrative reforms in public organizations have not produced substantial changes, neither in structure, nor process nor attitude. Leaders in such organizations tend to prefer to implement reform as a formality or simply to comply with rules and legislations, given the great risks they will face. This condition has encouraged a review of the role of leadership that must be undertaken so that substantive changes in public organizations can occur. A case study was conducted on an administrative reform process that resulted in substantial changes in the National Institute of Public Administration (NIPA), a key administrative body that undertook administrative reform at national level. The study found that in order to succeed in implementing substantial change, leaders must play the role of building change mindset for change, spokesperson for reform, pathfinding and demonstrate commitment.
\end{abstract}

Keywords: leadership role; administrative reform; public organizations

\section{INTRODUCTION}

Implementation of administrative reform in most public organizations have not produced substantial changes [1]. Changes in structure have often only reached the stage of moving one unit of an institution to another institution. Changes in process, have not been of much help either. They have not facilitated people who want to get those services. Neither have changes in attitude been observed nor felt by the users, stakeholders and society [2]. Changes that have been made in the remuneration of those working in the institutions have not been able to leverage their performance

Implementation of administrative reform is interpreted as a process of implementing reform policies in each and every public organization (organizational level). This concept of implementation follows that of Mazmanian and Sabatier who stated that implementation is a hierarchical implementation of policy objectives defined by the central government [3]. implementation is the process of translating policy into action. Referring to Meier and O'toole, Implementation interpreted to generating tangible results [4]. The concrete results, when referring to Longo and Cristofoli, are the development or effective transformation of each public organization [5]. Implementation of administrative reform at the level of public

Corresponding authors: Kamaruddin. organizations is important to note, because the effectiveness of changes made to each of the public organizations will determine the impact of general administrative reform. Users, stakeholders and society that will benefit from reforms are directly related to each of the public organizations. When reforms have not been able to generate substantial change at the level of public organizations, then the users, stakeholders and society will not benefit from reform.

The fact that the Implementation of administrative reform has not produced substantive change can be understood when leaders in public institutions, who are expected to lead change, are more likely to carry out reform just as a mere formality or simply to follow procedures set by the central government. Superficial reforms are preferred, because they are considered safer as they do not cause the major risks [4] that would arise if the changes were substantial. As a consequence of this option, a number of programs that have been planned, such as institutional restructuring, have been rejected to this day.

Rejection of the implementation of reform, is always related to the risks and consequences that accompany it. Leaders who want to implement reform, will potentially face and or encounter various risks. Risks can arise from the resistance of parties who feel they will suffer from the consequences of change. The risk may occur in the form of intimidation, criminalization or even murder. The consequences of reform implementation can be either a loss of position or values [5]. This consequence is certainly undesirable to anyone, but This consequence is certainly not desired by anyone. However, whatever the risk is, if change is greatly needed by a public organization, then that change must be made.

Looking at the achievements of reform implementation and referring to Beer, Eisenstat and Spector, most reform implementation is guided by the theory of change that has itself fundamental limitations [6]. One of them concerns the role of leadership in change and the role that must be assumed. Fernandez and Rainey and Rainey, for example, assert that the success of making changes in public organizations depends on the support and commitment of the top level civil servant [7][8]. This means that the highest level career leaders (PNS or Civil Servants) must support and or lead the reform process by taking on the role which Kee, Davis and Newcomer named 
the architect of change [9]. This concept could create a conflict of interest, if applied to a reform context whose goal is to streamline the organizational structure. When reform demands streamlining the organizational structure, and the role of reform architect is played by the highest level of career leaders (PNS) who would logically want to retain their positions, their support and commitment to reform will be hard to come by. Theoretical explanation of Kee, Davis and Newcomer, also has another limitation, namely the difficulty in achieving collectivity of all levels of leadership. The necessity for this collectivity is problematic because in public organizations (at each level of leadership) consists of many interests. A coalition for change which involves people whose interests will be disturbed by the changes to be implemented will complicate the implementation of reform.

To address these theoretical limitations, the implementation of administrative reforms at the National Institute of Public Administration (LAN) is an interesting case to be considered. Since the government started implementing bureaucratic reforms, NIPA has made a number of fundamental changes [10]. These changes include, organizational restructuring, personnel system changes, changes in organizational culture, and changes in staff education and training policies.[11] Interestingly, the fundamental changes in LAN have been pursued over several leadership periods, but have only been implemented under the current leadership. [11]

The implementation of the reforms in the NIPA would be appropriate for a more in-depth study to gain lessons from the experiences that resulted in the development or transformation of a public institution, particularly in the implementation of reforms that faced formidable obstacles or those that logically generated resistance. This review will focus on the role of leadership in the implementation of administrative reform at the level of public organizations.

\section{RESEARCH METHOD}

The present research was a case study at National Institute of Public Administration (NIPA) of the Republic of Indonesia which was based on the Post-Positivist paradigm. The case study design was chosen to develop the theory accordance with the main purpose of this study [12]. Data were collected through in-depth interviews with a number of informants. Informants were chosen by using purposive technique. Key informants in this study were the officers of NIPA in the period 2012-2014, comprising Agus Dwiyanto as Head of NIPA, Desi Fernanda, Endang Wirjatmi, Mahdum Priyatno and Sri Hadiati as Deputy officers, Adi Suryanto, Anwar Sanusi and Triwidodo Wahyu Utomo as NIPA bureaucratic Reform Team. The informants from outside the NIPA were Muhammad Yusuf Ateh as Bureaucratic Reform Deputy Officer of the Ministry of Administrative and Bureaucratic Reform. In addition, secondary data were collected through documents, such as the NIPA Bureaucratic Reform Roadmap and the Bureaucratic Reform Progress Report. Processing and data analysis in this research consisted of five (5) stages, namely 1) sorting and classifying, 2) opened coding, 3) axial coding, 4) selective coding, and 5) translating and investigating (Neuman, 2013). Validity in this study obtained in two ways:(1) triangulating information on various sources of data by examining evidence of amplifier, (2) collecting experts' views on the credibility and interpretations of the findings [13].

\section{RESULT AND DISCUSSION}

\section{A. Building Change Mindset}

The implementation of Bureaucratic Reform in LAN is actually based on the roadmap designed by the Ministry of PAN and RB. But apparently, bureaucratic reforms in LAN not only rely on the roadmap, but made their own plans based on LAN's needs and challenges which were then put in a map that they called the intangible roadmap. In the process, it was very difficult to get a consensus on the plan of change; thus, when the pace of change began to be hampered by obstacles, it was the head of the LAN who determined the direction. These directives were related to principle matters, such as the vision to be realized by LAN in the future, the need for the adoption of experiential learning in the new pattern for the training of leaders, the application of open recruitment for officials, consolidation of authority within the organizational structure, and quality standards which were the results of studies.

\section{B. Pathfinder}

The implementation required strong support so that repellents groups could not inhibit. But relying on formal communication channels could not produce the required support. Therefore, it was necessary to utilize all available communication channels. Establishing and utilizing nonformal communication channels was one path done by NIPA Head to build support from various NIPA units and organizational functions. Non-formal communication can be constructed deliberately by leaders to distribute information, advice, suggestions, even commands that are associated with change [14]. Using this communication channel, the leader is able to communicate directly with responsive staff or directly consolidate them to support change. Non-formal communication was conducted through informal meetings, for example utilizing the time after physical fitness exercises or doing planned non-formal meetings. This non-formal meeting was conducted with anyone who concerns the change, regardless of the hierarchy of positions in the organizational structure of the NIPA. Non-formal communication became communication strategy chosen by Head of NIPA, when communication through formal channels or communications that follow the hierarchy of the organization did not produce enough change support to be able to mobilize the change process.

In terms of reform in NIPA, the limited availability of budget, staff, and time has not been an obstacle in the implementation of change. The availability of resources is important to support change, but it does not mean that limited resources would necessarily stop change from occurring. The limited resources in NIPA during the reform were managed using a number of strategies, namely synergizing staff 
members, developing a high spirit, and treating change as a process which is both dynamic and open. As a form of synergy, personal limitations were overcome through a cross functional team in implementing the change programs. The new pattern and system of training, for example, are seen as a dynamic training system, which are still open for improvement both in concept and implementation. As a consequence, there have been several unsatisfactory results, such as the delivery of training using the new pattern but without proper preparation. Hence, good preparation should be constantly strived for before training is conducted.

Other ways were also found and used by NIPA heads, when an established change team or formal structures that involved and relied on existing organizational hierarchy levels were less able to boost the change rate. The path was to set up an ad hoc team working on the tasks of change that had not been able to do. This path was taken to ensure that the changes could hold effectively or they were not postponed minimally. Head of the National Institute of Public Administration (NIPA) do more consolidating for the staffs of the National Institute of Public Administration who were categorized into second and third echelons and functional officers to become agents of change in their respective units. The head of the National Institute of Public Administration along with the agent of change would hold an informal meeting to discuss about changes need to be done at the National Institute of Public Administration. The head of NIPA chose to consolidate young staff as a strategy to mobilize the power of change more quickly and effectively. Through this strategy, the Head of the National Institute of Public Administration could directly meet with people who were responsive to change and choose them to be ad hoc team members who were deliberately set up to prepare the design of change or take over responsibility in running the constrained idea of change.

\section{Spokesperson}

The Head of LAN is an exemplary example and a negotiator in getting the resources required. Acting as a role model, the Head of the LAN internalized the new values of the bureaucracy, among others, that officials should not be honored because of their position; thus, it was not necessary to address them by their positions, but simply by their names. The LAN chief exemplified this by refusing to be addressed by the name of his position.

As a prominent professor of a high-ranking university in Indonesia and as a former consultant at the Ministry of Home Affairs, it was not difficult for the Head of LAN to act as a negotiator. He also had a wide network both within and outside the country. This reputation became his asset to convince the parties concerned, especially external parties. External support for change in LAN, was obtained directly from the Minister of PAN and RB and the Vice President. Support was also obtained from the Head of the Education and Training Agency of the Ministry of Home Affairs. Support from the Education and Training Agency was obtained from the collaboration between LAN and the Education and Training Agency in the implementation of the new training pattern. Through this external support, the rate of change in LAN could be accelerated and the resistance to change decreased dramatically

\section{Demonstrate Persistent and Commitment}

Making changes required the implementing parties to be prepared for all the consequences, of course after mapping all possible risks that could arise. The Head of the LAN was threatened with prosecution over his decision, was also threatened with a budget freeze during a meeting with the House of Representatives. He was also once visited by an employee who questioned the grounds by which he had been moved from his position. He also faced fierce debates in leadership meetings. Faced with all that, the LAN Head remained a staunch implementer of change and he always explained in great length all the logical arguments of every action taken. When an officer was to be replaced, for example, he would summon the officer to explain that he had not committed any wrong, but that the change of position was required to accelerate the change process.

It is taken for granted that each public organization already has or has always had a leader. But the existence of such leadership is not always able to bring about change for the better to the organization, even though change is needed. According to Kotter, it would be more appropriate for such leaders to be called managers, because managers have the function of establishing stability through estimates and rules [15] while leaders having a number of roles will always bring improvement and change, which according to Yukl are their main function [16].

Kee, Davis and Newcomer have explained that, leadership roles in public sector change require collective leadership at each level. Collective leadership, consists of three leadership levels: elected political leaders, career leaders and supervisors. Effective change in public organizations (government) requires the collectivity of all three, in other words complementary action at all levels of leadership. The collectivity in such actions requires a clear description of the main responsibilities of political leaders, career leaders and supervisor level leaders. When collectivity is able to operate, the requirements for successful change have been met. Political leaders play the role of advocate, career leaders act as architects, and supervisors take on the interpersonal role.

Given the important role of career leadership as architects of change, Fernandez and Rainey (2006) agree with Holzer and Callahan, that many of the significant changes occurring in a government require and/or are led by career leaders. Rainey even sees top management support and commitment, the top level civil servants, as a determinant factor for successful implementation of public sector organizational change.

If this concept were applied rigidly, for example in the context of organizational restructuring, then it is understandable why it did not achieve its objectives. Waiting for an indeterminate period of time for the commitment and support from a certain level of leadership could be a barrier to the change process. The existence of the collectivity prerequisites appears to be in conflict with Lewin's field of 
force analysis theor. In addition, it will be difficult for collectivity to occur given that there are many interests in public organizations that are not only different but even contradictory. Therefore, this study not only explains what role leaders should play in order for administrative reform to be implemented, but also how those roles of the role can be assumed.

This study found that support can be obtained and derived from any function or unit. If change does not get support from a certain level of leadership, it does not mean that the change will not work. Support for any change can be established through any communication paths, both formal and nonformal channels. When one path is ineffective then another path can be utilized. If the formal structure is not effective, then the leader can make use of an ad hoc team. This confirms that, whatever the problems hindering the pace of the reform process, the leader only needs to find a way out and be consistent and persistent in carrying it out.

\section{CONCLUSION}

This study confirms that a number of leadership roles found in the literature still persist, and new roles can be developed. In this case the role of leadership for the successful implementation of administrative reforms in public organizations was to building change mindset, Pathfinding, spokesperson, and demonstrate persistent and commitment. The four roles - building change mindset, Pathfinding, spokesperson, and demonstrate persistent and commitmenttogether define the job the reform leader. They are all should serve as a compass for public organization leader seeking to find their way amid the resistance and pressure for successfuly implementing administrative reform.

\section{REFERENCES}

[1] E. Prasojo. Second Reform: Continuing the Reformation Reform. Salemba Humanika. Jakarta, 2009

[2] A. Dwiyanto. Contextual Bureaucratic Reform: Returning to the Right Path (Reformasi Birokrasi Kontekstual: Kembali Ke Jalan yang Benar). MAP UGM-Lembaga Administrasi Negara. 2015

[3] D.H.Mazmanian and P.A. Sabatier,.Implementation and Public Policy. New York: Harper Collins. 1983

[4] K.J Meier dan O.J Laurence Bureaucracy In A Democratic State: A Governance Perspective. USA: The John Hopkins University Press. 2006

[5] F. Longo and D. Cristofoli. Strategic Change Management in The Public Sector. John Wiley \& Son, Ltd. 2007

[6] A. Khassawneh. "Change Resistance in Bureaucratic Organizations in Jordan: Causes and Implications for Future Trends of Administrative Reform and Development". J. King Saud Univ., Vol. 18, Admin. Sci. (1), 2005. pp. 15-39, Riyadh (1426H./2005)

[7] J.P Kotter,dan L. A. Schlesinger. Choosing Strategies For Change. In Harvard Business Review, 1979. Vol. 57, pp106-140.

[8] M.Beer; R. A., Eisenstat, and B Spector. Why change programs do not produce change. Harvard Business Review, 1990. 68(6), 158-166.

[9] S.Fernandez and H.G. Rainey. Managing Successful Organizational Change in the Public Sector, Public Administration Review, 2006. 66, 2,168-76.

[10] H.G. .Rainey. Understanding and Managing Public Organizations, 2nd edn. San Francisco, CA: Jossey-Bass. 1997

[11] R. Morse. Transforming Public Leadership for the 21st Century. M.E. Sharpe, Inc. 2007

[12] http: // lan.go.id/en/lan-news/program-rb-kian-membaik-lan-dipastikandapat-kenaikan-tunjangan-kinerja

[13] Bureaucratic Reform Progress Report LAN of 2014

[14] R.K. Yin. Case Study Research: Design and Methods (Applied Social Research Methods). Illinois : Sage Publications. Inc. 2008

[15] J.W. Creswell. Research Design. Qualitative, Quantitative, and Mixed Methods Approaches. Third Edition. California. Sage Publication. 2009

[16] H.A Simon. Administrative Behavior: A Study of Decision Making Process. New York: Macmillan 1947

[17] J.P Kotter. Leading Change, Harvard Business School Press. 1996

[18] G. Yukl. Leadership in Organizations. Seventh Edition, Prentice Hall. 2008 